See discussions, stats, and author profiles for this publication at: https://www.researchgate.net/publication/343988756

\title{
Changes from Cliff- to Tree-Nesting in Raptors: A Response to Lower Human Persecution?
}

Article in Journal of Raptor Research · August 2020

DOI: 10.3356/0892-1016-55.1.119

\section{CITATIONS}

3 authors:

Alejandro Martínez-Abraín

University of A Coruña

108 PUBLICATIONS 2,189 CITATIONS

SEE PROFILE

Miguel Ferrer

Spanish National Research Council

233 PUBLICATIONS 6,847 CITATIONS

SEE PROFILE

Some of the authors of this publication are also working on these related projects:

Conservation Spanish imperial eagles View project

Collaborative Research: Intermountain Bird Observatory (USA) and Fundación Migres (Spain) View project

\section{READS}

172

Juan Jiménez

Generalitat Valenciana

61 PUBLICATIONS 778 CITATIONS

SEE PROFILE 


\title{
LETTER
}

J. Raptor Res. 55(1):000-000

(C) 2021 The Raptor Research Foundation, Inc.

\section{Changes from Cliff- to Tree-nesting in Raptors: A Response to Lower Human Persecution?}

\author{
Alejandro MARTínez-ABraín \\ Universidade da Coruña, Evolutionary Biology Group (GIBE), Facultad de Ciencias, Campus da Zapateira s/n,
} 15008 A Coruña, Spain

JUAN JIMÉNEZ

Generalitat Valenciana, Servicio de Vida Silvestre, Ciutat Administrativa 9 d'Octubre, Torre 1, C/ Democracia, 77, 46018 Valencia, Spain

\author{
MigUEL FERRER ${ }^{1}$ \\ Applied Ecology Group, Estación Biológica de Doñana, CSIC. C/Américo Vespucio 26, 41092 Isla de la Cartuja, Sevilla, Spain
}

KEY WORDS: cliff nesting; facultative behavior, human attitudes; human persecution; nesting substrate; population recovery; tree nesting.

Human persecution of top predators has been historically very intense worldwide. In many countries, top predators have been or are still persecuted because they are considered competitors for resources, especially within subsistence economies (Bildstein 2008, Madden et al. 2019). As a result, many large mammalian predators have adapted their behavior to avoid humans, in extreme examples becoming nocturnal (Gaynor et al. 2018). In southern Europe, centuries- or millennia-old and intense historical persecution of large predators can be traced from the time of the Roman Empire to the present (Jennison 1937). However, the level of persecution has decreased substantially during the last few decades. This shift has been mainly driven by diverse socio-economic changes and the associated new human attitudes toward wildlife (MartínezAbraín et al. 2008, 2009, Mayhew et al. 2016, MartínezAbraín and Oro 2018), in combination with awareness campaigns and conservation laws. In addition, fewer humans live near wild lands and wildlife in Spain than in the past years. Human population density in Spain is 92 inhabitants $/ \mathrm{km}^{2}$; well below the European mean (177 inhabitants $/ \mathrm{km}^{2}$ ). Most Spaniards live now in large cities $(51 \%)$, a result of a rural exodus that started in the $1950 \mathrm{~s}-$ 1960 s and is still ongoing. Currently, a large part of the Spanish territory (53\%) has densities lower than the threshold used by the European Union to classify a territory as sparsely populated or depopulated (11.5 inhabitants/ $\mathrm{km}^{2}$ ).

\footnotetext{
${ }^{1}$ Email address: mferrer@ebd.csic.es
}

This centuries- or millennia-old persecution of top predators most likely has shaped many aspects of the present ecology of large predators both via selection and cultural processes (Martinez-Abraín et al. 2019). One of the animal traits most susceptible to negative influence by historical human persecution is habitat selection and, in particular, nesting habitat selection. For example, Fernández (1993) found that Golden Eagles (Aquila chrysaetos) not only choose cliffs for nesting-due to human disturbance-but also that they choose the most inaccessible cliffs that are located farthest from tracks, roads, and villages. Osprey (Pandion haliaetus) populations from northern Europe (less intensively persecuted during the last century) nest on trees, whereas Mediterranean populations (most intensively persecuted in the recent past) nest on island cliffs (Ferrer and Morandini 2018, MartínezAbraín 2018, Monti et al. 2018). A similar situation exists with the Booted Eagle (Aquila pennata): on the island of Mallorca (Spain), the eagles currently nest on cliffs after a long period of intense human persecution, but in the Iberian Peninsula, they are tree-nesters (Viada and de Pablo 2009). In a systematic review, Martínez-Abraín et al. (2010) found that large raptors nesting in trees exhibited greater displacement distances from roads (using roads as a proxy of human presence) than large raptors nesting on cliffs. Similar examples of negative demographic consequences for obligate tree nesters under strong human persecution include the Great Spotted Eagle (Aquila clanga) that was extirpated from Finland during the first half of the $20^{\text {th }}$ century, whereas other large facultative treenesting species, such as the Golden Eagle, persisted (PohjaMykrä et al. 2012); however, evidence was equivocal, as several obligate tree nesters were affected much less or not at all (Pohja-Mykrä et al. 2012). Likewise, the White-tailed 
Table 1. Number of breeding pairs over time in Spain of two facultative tree/cliff nesters (left columns) and two obligate tree nesters (right columns). The numbers of Golden Eagle pairs for 1984, 1990, and 2008 are minimum values of the range estimates.

\begin{tabular}{|c|c|c|c|c|c|c|c|}
\hline \multicolumn{2}{|c|}{ Golden EaGle } & \multicolumn{2}{|c|}{ BONELLI'S EAGLE } & \multicolumn{2}{|c|}{ SPANISH IMPERIAL EAGLE } & \multicolumn{2}{|c|}{ Cinereous Vulture } \\
\hline YEAR & PAIRS & YEAR & PAIRS & YEAR & PAIRS & YEAR & PAIRS \\
\hline 1984 & 998 & 1987 & 620 & 1981 & 104 & 1989 & 774 \\
\hline 1990 & 1190 & 1990 & 680 & 1990 & 140 & 1993 & 1027 \\
\hline \multirow{3}{*}{2008} & 1553 & 2000 & 710 & 2000 & 240 & 2006 & 1854 \\
\hline & & 2005 & 733 & 2013 & 407 & 2014 & 2068 \\
\hline & & 2018 & 710 & 2017 & 520 & & \\
\hline
\end{tabular}

Eagle (Haliaetus albicilla) was extirpated from Scotland, where it bred only as a tree-nester, whereas the Golden Eagle, a facultative tree nester, persists to the present (Evans et al. 2012).

All these examples suggest that nesting on trees makes raptors more vulnerable to human disturbance than nesting on cliffs. Facultative tree/cliff nesting by raptors likely evolved as an adaptation to increase plasticity in relation to habitat availability along with intra- and interspecific competition for nesting space. Several suggestions can be made about why some raptor species seem to be much more plastic than others, including the habitat of origin for the species (Ferrer 2019, Martínez-Abraín and Jimenez 2019). Alternatively, from a conservation perspective, the ability to nest on trees or cliffs might have been helpful for avoiding historic human persecution simply by allowing increased options for nest sites that minimized the potential for conflict.

If obligate tree-nesters (i.e., species never recorded breeding on cliffs) are more sensitive to human persecution than facultative tree-nesters (i.e., species that breed on both substrates), we might predict that the population recovery of obligate tree-nesters in recent decades should have been proportionally stronger than that of facultative tree/cliff nesting species. This would have resulted because obligate tree-nesters suffered stronger declines in the past due to their lack of capacity to shift from trees to cliffs when affected by direct persecution. We might also predict that the proportion of nests of facultative species placed on trees versus cliffs would have increased during the last few decades as direct persecution of raptors by modern urban people in Europe declined.

To test the role of nesting substrate on changes to population size, we collected information on abundance over time (1980 to present) for four large raptor species in Spain: two facultative tree-nesters, Golden Eagle and Bonelli's Eagle (Aquila fasciata) and two obligate treenesters, Spanish Imperial Eagle (Aquila adalberti) and Cinereous Vulture (Aegypius monachus; Martínez-Abraín and Jiménez 2019). We also analyzed the proportion of nests on trees versus cliffs for the two facultative species, Golden Eagle and Bonelli's Eagle. All these species are large, long-lived species with high annual survival probabilities, low fecundities, and delayed sexual maturity.

We obtained population size data for an entire southern European country (Spain) from available national censuses and diverse specialized bibliographies (Equipo de Estudio del Águila Real y el Águila Perdicera 1987, Arroyo et al. 1990, 1995, Gonzalez 1990, Ferrer 2001, Real 2004, De la Puente et al. 2007, Del Moral 2006, 2009, 2019, SEO/ BirdLife (in press), Sánchez 1998 and references therein, Spanish Imperial Eagle Working group, proyecto monachus.grefa.org/el-buitre-negro/). Both groups of species (facultative and obligate tree-nesters) have increased since the $1980 \mathrm{~s}$; however, the magnitude of the increase varied for the species in each group (Table 1 ). The population growth rates, or lambdas $\left(\lambda=N_{t+1} / N_{t}\right)$, for facultative tree-nesters (Golden and Bonelli's Eagles) were 1.2 and 1.1 respectively, indicating mean decadal increases of $20 \%$ and $10 \%$ respectively. Lambdas for obligate tree nesters (Spanish Imperial Eagle and Cinereous Vulture), however, were 1.5 and 1.4 , indicating mean decadal increases of $50 \%$ and $40 \%$ respectively. The higher lambda for obligate tree nesting raptors during our target time period is likely because their populations were much lower in the 1980 s, potentially as a result of human persecution, leading to a more marked population increase. The more plastic behavior of facultative nesters could have helped them better tolerate past human persecution.

Although population growth rate increased more for obligate tree-nesting raptors than for facultative treenesting raptors, there are other potential explanations beyond the influence of persecution. For example, funds for conservation may also explain differences in population growth rates among groups, with some species benefitting from more total funds spent for targeted conservation actions. However, one obligate (Spanish Imperial Eagle) and one facultative (Bonelli's Eagle) species were supported by European Union funds and, although both increased, the Spanish Imperial Eagle increased at a higher rate. Similarly, Golden Eagles and Cinereous Vultures did not benefit from significant EU funds and also increased at different rates. Hence, we do not think the amount of 


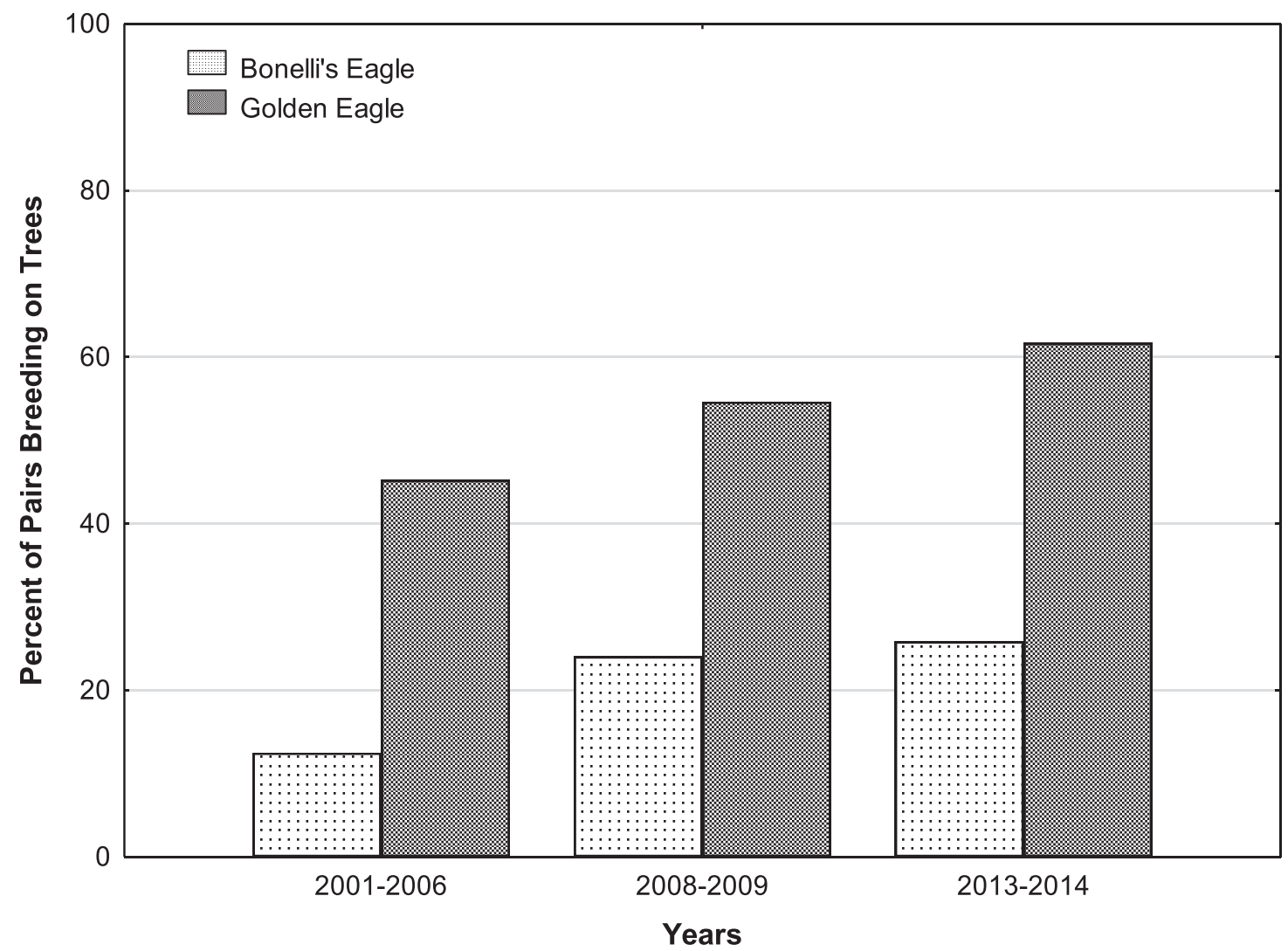

Figure 1. Percentages of Bonelli's and Golden Eagle pairs breeding on trees (Sierra Morena area, Andalusia, Spain), during the period 2001-2014. There is a trend for increased proportion of nests on trees vs. cliffs in both species.

investment in conservation can explain the differences in recovery rates between the two raptor groups.

To assess variation in the proportions of tree versus cliff nesters in facultative species (i.e., Golden and Bonelli's Eagles), we selected a large and well-monitored region in southern Spain (Sierra Morena, Andalusia) where both substrate types are widely available. According to some authors (Arroyo et al. 1990, 1995, Del Moral 2006, 2009), these cliffs cannot be considered to be saturated with nests and so availability is not a limiting factor. The Andalusian Environmental Administration provided data on the proportion of tree/cliff nests for Golden Eagle (2006 vs. 2014) and Bonelli's Eagle (2001 vs. 2013).

For both species, the proportion of tree vs. cliff nests used has increased over time (Fig. 1). In Andalusia, 38 pairs of Golden Eagles nested on trees in Sierra Morena in 2006 ( $45.2 \%$ of the total population), whereas 52 pairs were tree nesters in 2014 (61.7\% of the total population; a $40 \%$ increase in $8 \mathrm{yr}$, Fisher exact test $P=0.0244)$. Likewise, six pairs of Bonelli's Eagles (12.5\% of the total population) nested on trees in Sierra Morena in 2001 whereas 12 pairs nested on trees in 2013 (25.8\% of the population, a 100\% increase in $12 \mathrm{yr}$; Fisher exact test $P=0.0634$ ). To our knowledge, no nests of Spanish Imperial Eagles or Cinereous Vultures were found on cliffs in Spain.

Because large, tree-nesting raptors may be more susceptible to human persecution, the increase in the percentage of nests built on trees in Spain during the last few decades might be explained by the reduction in direct human persecution (Martínez-Abraín et al. 2013). But other factors may also have influenced the documented increase in the use of trees for nesting. For example, intraor interspecific competition may have acted as a proximate trigger of cliff abandonment, perhaps in parallel with population recovery of many species across the associated communities. In fact, many large species are now recovering from past persecution, which in turn can cause negative effects to smaller species. For example, common Griffon Vultures (Gyps fulvus; minimum of 30,946 pairs in 2018 in Spain; Del Moral and Molina 2019) have been reported stealing nest material from 
Bonelli's Eagles (Jiménez 2019), which could force eagle pairs to abandon cliff nests.

Alternatively, it is possible that the increasing number of tree nests reflects pairs relegated to suboptimal habitat due to increasing population density and limited numbers of breeding sites available. It would be interesting to determine whether the productivity of the new treebreeding pairs is lower than the productivity of cliffbreeders. If true, this could lend support to the proposed explanation. According to the habitat heterogeneity hypothesis $(\mathrm{HHH})$, as density rises, an increasing proportion of individuals are relegated to lower quality habitats, leading to declines in mean population fecundity (Ferrer and Donázar 1996). However, considering that the availability of cliff nest sites is still high (see above), this potential explanation does not seem very plausible.

Another alternative explanation for the increasing percentage of tree-nesters in facultative tree/cliff nesting species would be changes in distribution and abundance of prey. A change in the distribution of high density areas of prey away from potential cliff-nesting sites together with a general increase in prey populations could be the reason for an increase in tree nesters. However, due to several infectious diseases during recent decades, the density of wild rabbits (Oryctolagus cunniculus; the main prey for raptors in Spain) is far lower than in the past, suggesting that changes in density or distribution of prey are not the main factors driving these changes (Ferrer and Negro 2004).

More detailed study of the role played by direct human impacts on nest site substrate selection could help inform future policymaking, and guide conservation activities for facultative cliff/tree nesting raptors worldwide. Reintroduction or population supplementation programs could benefit from this new perspective through consideration of identified behavioral patterns. For example, selection of nesting substrate by raptors could be part of the traits linked to the shy-bold behavioral complex (Bell 2007, Réale et al. 2007). Changes in fear of humans, aggressiveness, and exploratory behavior have been identified in urban birds as a response to changes in human density, with a higher frequency of bold behaviors in areas having higher human density (Riyahi et al. 2015, 2017). Additionally, an increase in the intensity of nest defensive behavior over the years in relation to human presence has been documented in both large and small raptors (Ferrer et al. 1990, 2007, Arroyo et al. 2017). This increase suggests that bold defensive behavior, including striking humans, could have been positively reinforced when adults did not lose their offspring after a hypothetical human attack. The use of bold young from tree-nesting populations in hacking programs, implemented in areas with high but harmless human presence, could introduce behavioral plasticity into populations of shy individuals, likely leading to improved success (Réale et al. 2007, Martínez-Abraín 2018).

\section{ACKNOWLEDGMENTS}

This study received funding from project "Programa de Investigación Competitiva del Sistema Universitario Gallego, ED431C 2018/57". Three anonymous referees greatly improved early versions of this Letter.

\section{Literature Cited}

Arroyo, B., E. Ferreiro, and V. Garza (1990). El Águila Real (Aquila chrysaetos) en España: Censo, Distribución, Reproducción y Conservación. ICONA-Ministerio de Agricultura, Pesca y Alimentación, Madrid, Spain.

Arroyo, B., E. Ferreiro, and V. Garza (1995). El Águila Perdicera (Hieraaetus fasciatus) en España: Censo, Reproducción y Conservación. ICONA-Ministerio de Agricultura, Pesca y Alimentación, Madrid, Spain.

Arroyo, B., F. Mougeot, and V. Bretagnolle (2017). Individual variation in behavioural responsiveness to humans leads to differences in breeding success and long-term phenotypic population changes. Ecology Letters 20:317-325.

Bell, A. M. (2007). Future directions in behavioural syndromes research. Proceedings of the Royal Society of London 274:755-761.

Bildstein, K. L. (2008). A brief history of raptor conservation in North America. In The State of North America's Birds of Prey (K. L. Bildstein, J. P. Smith, E. R. Inzuza, and R. T. Veit, Editors). Nuttall Ornithological Club American Ornithologists' Union Series in Ornithology 3:5-36.

De la Puente, J., R Moreno-Opo, and J. C. Del Moral (Editors) (2007). El Buitre Negro en España: Censo Nacional (2006). SEO/BirdLife, Madrid, Spain.

Del Moral, J.C. (Editor) (2006). El Águila Perdicera en España: Población en 2005 y Método de Censo. SEO/ BirdLife, Madrid, Spain.

Del Moral, J.C. (Editor) (2009). El Águila Real en España: Población Reproductora en 2008 y Método de Censo. SEO/BirdLife, Madrid, Spain.

Del Moral, J. C., and B. Molina (Editors) (2019). El Buitre Leonado en España: Población Reproductora en 2018 y Método de Censo. SEO/BirdLife, Madrid, Spain.

Equipo de Estudio del Águila Real y el Águila Perdicera (1987). Primera encuesta sobre el águila real Aquila chrysaetos y el águila perdicera Hieraaetus fasciatus en la península Ibérica. In Proceedings of the $5^{\text {th }}$ International Conference on Mediterranean Raptors. Évora, Portugal.

Evans, R. J., L. O'Toole, and D.P. Whitfield (2012). The history of eagles in Britain and Ireland: An ecological review of place name and documentary evidence from the last 1500 years. Bird Study 59:335-349.

Fernández, C. (1993). The choice of nesting cliffs by Golden Eagles Aquila chrysaetos: The influence of accessibility and disturbance by humans. Alauda 61:105-110. 
Ferrer, M. (2001). The Spanish Imperial Eagle. Lynx Edicions, Barcelona, Spain.

Ferrer, M. (2019). Cliffs, trees, and ground-nesting raptors. Ideas in Ecology and Evolution 12:26-27.

Ferrer, M., and J. A. Donázar (1996). Density-dependent fecundity by habitat heterogeneity in an increasing population of Spanish Imperial Eagles. Ecology 77:6974.

Ferrer, M., L. García, and R. Cadenas (1990). Long-term changes in nest defence intensity of the Spanish Imperial Eagle, Aquila adalberti. Ardea 78:395-398.

Ferrer, M., and V. Morandini (2018). The recovery of Osprey populations in the Mediterranean basin. Ibis 160:923-925.

Ferrer, M., and J. J. Negro (2004). The near extinction of two large European predators: Super-specialists pay a price. Conservation Biology 18:344-349.

Ferrer, M., J. J. Negro, E. Casado, R. Muriel, and A. Madero (2007). Human disturbance and the conservation of the Spanish Imperial Eagle: A response to Gonzalez et al. (2006). Animal Conservation 10:293-294.

Gaynor, K. M., C. E. Hojnowski, N. H. Carter, and J. S. Brashares (2018). The influence of human disturbance on wildlife nocturnality. Science 360:1232-1235.

González, L. M. (1990). Situación de las poblaciones de águila imperial y buitre negro en España. Quercus 58:16-22.

Jennison, G. (1937). Animals for show and pleasure in ancient Rome. Manchester University Press, Manchester, UK.

Jiménez, J. J. (2019). Nido de águila perdicera desmantelado por buitres leonados. Quercus 401:43-44.

Madden, K. K., G. C. Rozhon, and J. F. Dwyer (2019). Conservation Letter: Raptor persecution. Journal of Raptor Research 53:230-233.

Martínez-Abraín, A. (2018). Satellite factors influencing the impact of recreational activities on wildlife. Animal Conservation 21:461-462.

Martínez-Abraín, A., J. Crespo, M. Berdugo, L. Gutiérrez, A. Lafuente, A. Mañas, and J. M. de Miguel (2013). Causes of human impact to protected vertebrate wildlife parallel long-term socio-economical changes in Spain. Animal Conservation 16:286-294.

Martínez-Abraín, A., J. Crespo, J. Jiménez, J. A. Gómez, and D. Oro (2009). Is the historical war against wildlife over in Southern Europe? Animal Conservation 12:204-208.

Martínez-Abraín, A., J. Crespo, J. Jiménez, A. Pullin, G. Stewart, and D. Oro (2008). Friend or foe: Societal shifts from intense persecution to active conservation of top predators. Ardeola 55:111-119.

Martínez-Abraín, A., and J. Jiménez (2019). Stick supply to nests by cliff-nesting raptors as an evolutionary load of past tree nesting. Ideas in Ecology and Evolution 12:2125.

Martínez-Abraín, A., J. Jiménez, and D. Oro (2019). Pax Romana: "Refuge abandonment" and expansion of fearless behaviours in a reconciling world. Animal Conservation 22:3-13.

Martínez-Abraín, A., and D. Oro (2018). Nocturnality decreases under low human disturbance conditions. Science (e-letter, 3 July 2018). http://science. sciencemag.org/content/360/6394/1232/tab-e-letters.

Martínez-Abraín A., D. Oro, J. Jiménez, G. Stewart, and A. Pullin (2010). A systematic review of the effects of recreational activities on nesting birds of prey. Basic Applied Ecology 11:312-319.

Mayhew, M., I. Convery, R. Armstrong, and B. Sinclair (2016). Public perceptions of a White-tailed Sea Eagle (Haliaeetus albicilla L.) restoration program. Restoration Ecology 24:271-279.

Monti, F., D. Gremillet, A. Sforzi, G. Sammuri, J. M. Dominici, R. Triay Bagur, A. Muñoz Navarro, L. Fusani, and O. Duriez (2018). Migration and wintering strategies in vulnerable Mediterranean Osprey populations. Ibis 160:554-567.

Pohja-Mykrä, M., T. Vuorisalo, and S. Mykrä (2012). Organized persecution of birds of prey in Finland: Historical and population biological perspectives. Ornis Fennica 89:1-19.

Real, J. (2004). Águila perdicera Hieraaetus fasciatus. In Libro Rojo de las Aves de España (A. Madroño, C. González, and J. C. Atienza, Editors). Dirección General para la Biodiversidad, SEO/BirdLife, Madrid, Spain. pp. XX-XX.

Réale, D., S. M. Reader, D. Sol, P. T. McDougall, and N. J. Dingemanse (2007). Integrating animal temperament within ecology and evolution. Biological Reviews of the Cambridge Philosophical Society 82:291-318.

Riyahi, S., M. Sánchez-Delgado, F. Calafell, D. Monk, and J. C. Senar (2015). Combined epigenetic and intraspecific variation of the DRD4 and SERT genes influence novelty seeking behavior in Great Tit Parus major. Epigenetics 106:516-525.

Riyahi, S., M. Björklund, F. Mateos-González, and J. C. Senar (2017). Personality and urbanization: Behavioural traits and DRD4 SNP830 polymorphisms in Great Tits in Barcelona city. Journal of Ethology 35:101-108.

Sánchez, J. J. (1998). The recovery of the Black Vulture Aegypius monachus in Spain. In Proceedings of the International Symposium on the Black Vulture in SE Europe and Adjacent Regions (E. Tewes, J. J. Sánchez, B. Heredia, and B. van Lexmond, Editors). Black Vulture Conservation Foundation, Frankfurt Zoological Society, Frankfurt, Germany. pp. 89-99.

SEO/BirdLife (2018). El Águila Perdicera en España: Población Reproductora en 2018 y Método de Censo. SEO/BirdLife, Madrid, Spain.

Viada, C., and F. de Pablo (2009). Cens d'àguila calçada Hieraaetus pennatus a Balears al 2009 i estat de conservació. Annuari Ornitològic Balear 24:1-15.

Received 8 May 2020; accepted 27 August 2020

Associate Editor: Ian G. Warkentin 
This article has been typeset from the submitted materials. Check proofs carefully for conversion or other inadvertent errors. Please follow the Allen Press Guide to PDF Annotation when marking revisions. Do not edit the PDF directly.

If present, queries will be listed below with corresponding numbers in the margins or may appear as PDF comments addressed to the author or editor. If a correction is desired in response to a query, mark the necessary changes directly in the proof using the appropriate annotation tool. If no change is desired, no action is necessary in response.

1. Author: Please provide page range for Real 2004. Stylemarker 